\title{
ENTERPRISE FACTORS AS AMBIDEXTERITY ANTECEDENTS: CONTINGENCY MODEL FOR AMBIDEXTROUS ORGANIZATIONS
}

\author{
*Farshin SALEHI \\ *Ali YAGHTIN \\ *Sharif University of Technology, Iran
}

\begin{abstract}
Ambidexterity broadly refers to an organization's ability to pursue two disparate things at the same time. Ambidextrous firms are capable of exploiting existing competencies as well as exploring new opportunities with equal dexterity. If a firm wants to gain these advantages and want to be ambidextrous; some organizational antecedents should support this strategy. Most researches focused on generally the inherent tension of ambidexterity elements or specifically an organizational factor as the antecedent. While according to the principle of strategic alignment, organizational performance is the consequence of fit between two or more factors such as strategy, structure, culture and environment. Therefore antecedents of organizational ambidexterity are investigated and organizational strategy, structures and culture are described as critical promoters of ambidexterity. Moving towards ambidextrous organization requires capable organizations of repeated change management at times of industry transitions that is expected not to be achieved without considering effective interplay of change in these three factors and their paradoxical behaviors.
\end{abstract}

This research addresses these gaps and presents a management model that seeks the balance of exploitative and explorative features of organizational strategy, structure and culture which is affected by environment. Our review resulted in the development of a management model that can be applied to describe, analyze, diagnose and promote ambidextrous organizations suggests that sustainable success can be achieved only if the organizations continuously balance paradoxical tensions of strategy, structure and culture concurrently.

Key Words: Organizational Ambidexterity, Exploitation, Exploration, Structure, Strategy, Culture.

\section{INTRODUCTION}

Economic downturns, like the current one, emphasize the need to respond to the rapidly changing market brings about challenges that organizations need to overcome in order to survive in the long run as well as fulfil short-term goals. Pursuing both these goals is proven to be a difficult task. In fact, most organizations do not survive in the long run (O'Reilly and Tushman, 2011). According to March (1991) organization activities should be monitored within exploration includes processes captured by conditions such as variation, risk taking, experimentation, flexibility, discovery and innovation, whereas exploitation concerns the terms like refinement, choice, production, efficiency, selection, implementation, and execution. Exploratory forecast and adapt to future trends while exploitative innovation fulfil immediate market needs. Being able to balance these two goals is described as organizational ambidexterity that was first coined by Duncan (1976). Ambidexterity involves the capability to both exploit existing knowledge, assets, and customers/markets for short-term profits and also explore new knowledge, technologies, and customers/markets to enhance long term development (O'Reilly \& Tushman, 2008). Researchers have increasingly come to recognize the importance of balancing seemingly contradictory tensions (Adler et al., 1999; J. S. Brown, J. S. \& Duguid, 2001; Katila \& Ahuja, 2002).

Several scholars regarded that there is a trade-off between aligning the organization to exploit existing competencies and exploring new ones (Ancona, Goodman, Lawrence, \& Tushman, 2001; Floyd \& Lane, 2000; Levinthal \& March, 1993). Earlier research had often claimed that organizational practices that simu ltaneously address efficient exploitation and effective exploration may be impossible to achieve (Gibson \& Birkinshaw, 2004, Hannan \& Freeman, 1977; McGill, Slocum, \& Lei, 1992; Miller \& Friesen, 1986 Simsek, 2009). In his 1991 article, March conversely argues that successful firms are ambidextrous contributed to a general shift in organizational research from trade-off to paradoxical thin king (Eisenhardt, 2000; Gavetti \& Levinthal, 2000; Lewis, 2000). 
While early conceptual research on organizational ambidexterity has been expanded to empirical studies on the relationship between organizational ambidexterity and firm performance (Gibson \& Birkinshaw, 2004; He \& Wong, 2004), how organizations achieve ambide xterity or the antecedents of balancing exp loration and exploitation are yet to be understood through further study (Jansen, Bosch \& Volberda., 2006; Gibson \& Birkinshaw, 2004).

Most of scholars studied ambidexterity and achieving the balance from the viewpoint of structure. Structural ambidexterity achieves the balance through temporal separation (Gupta, Smith and Shalley, 2006; Simsek et al., 2009), while contextual ambidexterity simultaneously explore and exp loit within a business unit (Gibson and Birkinshaw, 2004, Simsek et al., 2009). However few researches emphasize ambidexterity from the viewpoint of strategic management (e.g. Lubatkin et al., 2006; Smith and Tushman, 2005) and less is argued that ambidexterity is grounded in the type of organizational culture (Ghoshal and Bartlett, 1994; Gibson and Birkinshaw, 2004; Simsek et al., 2009).

Structure has a considerable impact on the development of organization using its content, dimensional and environmental aspects, it is considered to be one of the factors which enhance the productivity of organization. But as strategy is first formulated in organization and then managers develop structure, appropriate drafting of strategy must not be forgotten in a way that organization can fulfill its main objectives. This necessitates an appropriate culture within the organization that will support the organization in implementing strategies rather than an obstacle to the failure of strategy (Beygi, 2010).

Organizational structure and culture are typically part of strategic decisions of the top manag ement (Lyles and Schwenk, 1992). Studies have also proposed a variety of antecedents, and begun to specify more complex relationships and potential moderating effects (Auh \& Menguc, 2005; Jansen, van den Bosch, \& Volberda, 2006). Yet most researches focused on generally the inherent tension of a mbidexterity elements or specifically an organizational factor as the antecedent. Thus we see a need for an additional assessment of ambidexterity also from a 3dimentional perspective: Organizational strategy, structure and culture. This research addresses these gaps and presents a management model that designs Strategy, Structure and culture as three basic organizational factors paradoxically to achieve ambidextrous organization.

\section{CONCEPTUAL FRAMEWORK}

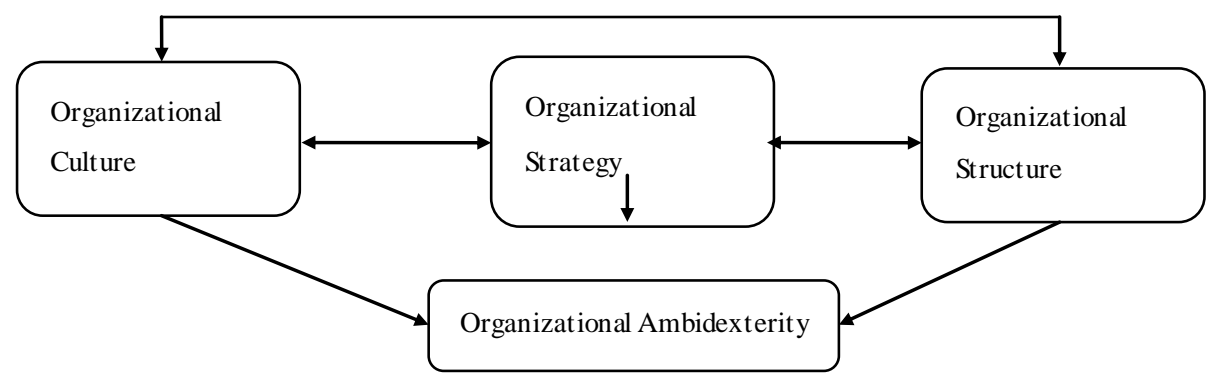

Fig 1. Organizational Ambidexterity Antecedents

\section{MUTUAL RELATIONS BETWEEN STRATEGY, STRUCTURE AND CULTURE}

Strategy refers to direction and scope of an organization over the long-term that achieves advantage for the organization through its configuration of resources with in a challenging environment, to achieve its markets, customers or client's acceptance and to fulfill stakeholder expectations (Johnson et al. 2008). Organizational strategy is long-term plan for organization which helps organization achieve its goals in a competitive environment (Benet, 1999). Organizational strategy emphasizes the monitoring and evaluation of external opportunities and threats in light of comparative strengths and weaknesses to generate and implement a new 
strategic direction (Hunger and Wheelen, 2007). It is a continuous, iterative process aimed at keeping an organization as a whole appropriately matched to its environment (Certo and Peter, 1991). Certo and Peter further state that organizational environments are constantly changing and organizations must be modified accordingly to ensure that organizational goals can be attained.

Strategy is the force that mediates between the firm and its environment. Firms whose strategy and structure are aligned should be less vulnerable to external changes and internal inefficiencies, and should thus perform better because "the structure provides the necessary systems and processes essential for succes sful strategy implementation" (Habib and Victor, 1991, p. 589). Chandler studied almost 100 of A merica's largest firms from 1909 to 1959. He concluded that organization structures follow the growth strategies of firms. In his 1962 groundbreaking work, Chandler showed that a long-term coordinated strategy was necessary to give a company structure, direction, and focus. He says it concisely; structure follows strategy (Chandler, 1962).

Structure, whether formally or informally defined, such as a built structure or a structure of society, has two aspects. It includes, first, the lines of authority and communication between different administrative offices and officers and second, the information and data that flows through the lines if communication and authority (Chandler 1962). The structure can affect the effectiveness of managers through the frequency of information among members, because the frequency of information facilitates knowledge distribution and sharing (Davenport \& Prusak, 1998). Organizational structure can be viewed as the way responsibility and power are allocated inside the organization and work procedures are carried out by organizational members (Blau, 1970; Dewar \& Werbel, 1979; Germain, 1996; Gerwin \& Kolodny, 1992).

Organizational structure models, as a particular configuration of structural dimensions, direct and shape the manner in which organization members perform their tasks in the course of achieving the organization's goals. Since both structure and culture determine the behavior of organization in different ways, it can be assumed that the model of the organizational structure influences organizational culture (Janićijević, 2013). Consequently researchers analyzed culture and structure and their mutual interaction (Wei, Liu, Hernd on, 2011; Singh, 2011; Zheng, Yang, McLean, 2010). It is quite possible that the compatibility of the behavior determined by the structural framework in an organization, and the behavior determined by cultural assumptions and values has an impact on strength or weakening of organizational culture. On the other hand, organizational culture realizes its impact on shaping organizational structure through forming the interpretative schemes of the top management, which selects the organizational structure model (James, James, Ashe, 1990).

Therefore the character of different components of management and organization, such as strategy and structure emerges precisely from the way in which employees and management understand organizational reality and behave in it which is organizational culture (Wilderom, Glunk \& Maslowski, 2000).

Culture has been identified as a pattern of shared assumptions, beliefs, and expectations that guide members' interpretations and actions by defining appropriate behavior within an organization (Fiol, 1991; O'Reilly \& Chat man, 1996). Cultural norms typically form around behaviors that are significant to a group such as how to interact with one another and prioritize objectives (e.g., Bettenhausen \& Murninghan, 1991). Organizational culture is a form of collective interpretative scheme shared by the members of an organization, due to which they assign meanings to occurrences, people, and events within and outside of the organization in a similar way and treat them similarly (Schein, 2004; Alvesson, 2002; Martin, 2002).

Many studies have tried to prepare some conceptual models and test the effect of organizational culture (Daulatru m B. Lund, 2003; Mehta and R.Krishnan, 2004; Zabid and Sambasivan, 2004; Naranjo-Valencia et. al., 2011). A noticeable in fluence of a powerful culture clears up on the subject of strategy implementation that only a few studied emphasize on the effect of culture on strategy implementation (SakuMantere, 2000; Van Der Maas, 2008). This is in line with previous studies which had considered relationships between organizational culture and organization's performance indicators (Fey and Denison, 2003; Pirayeh et.al., 2011; Ouchi, 1981; Lee and Tseng, 2005; Abdul Rashid et.al, 2004; Carnall, 1990; Naranjo-Valencia, 2011; Lopez et.al, 2004; Davenport and Prusak, 1997). 


\section{STRATEGY AND AMBIDEXTROUS ORGANIZATION}

A number of studies have provided arguments on paradoxical phrases assumed for strategy processes, albeit using different terms and mostly without referring to one another.

\section{Table 1: Contradictory Organizational Strategy Tensions}

\begin{tabular}{|c|c|c|}
\hline SCHOLAR & EXPLO ITATION STRATEGY & EXPLORATION STRATEGY \\
\hline Burgelman $(1991,2002)$ & Variation-Reducing or Induced & Variation Increasing or Autonomous \\
\hline \multicolumn{3}{|c|}{$\begin{array}{l}\text { The induced processes concern initiatives that are within the scope of the organization's current strategy and build on existing } \\
\text { knowledge, whereas the autonomous processes concern initiatives that emerge outside the current strategy's scope and involve the } \\
\text { creation of new competencies. He suggests that a combination of the two strategic processes may be the most beneficial, even though } \\
\text { this means that the organization never completely maximizes its efforts in the current domain. }\end{array}$} \\
\hline Ghemawat and Ricart i Costa (1993) & Static Efficiency & Dynamic Efficiency \\
\hline \multicolumn{3}{|c|}{$\begin{array}{l}\text { Static efficiency concerned about the refinement of existing products, processes, and capabilities. While dynamic efficiency concerned } \\
\text { about the development of new ones. They describe the organizational trade-off bet ween these two strategic processes and demonstrate } \\
\text { that organizations have a tendency to focus on only one. }\end{array}$} \\
\hline Hamel and Prahalad (1993) & Leverage & Stretch \\
\hline \multicolumn{3}{|c|}{ The need to ex ploit exist ing capabilities and the search for new ones is a key strategic challenge for creating competitive advantage. } \\
\hline Sanchez, Heene, and Thomas (1996) & Competence-Leveraging & Competence Building \\
\hline \multicolumn{3}{|c|}{$\begin{array}{l}\text { Successful firms have the capability of maintaining a mix of competence-leveraging and competence-building activities. Competence } \\
\text { leveraging refers to applying existing competences, whereas competence building refers to the development of new capabilities. }\end{array}$} \\
\hline $\begin{array}{l}\text { Volberda, Baden-Fuller, and van den } \\
\text { Bosch (2001) }\end{array}$ & Selective & Adaptive \\
\hline
\end{tabular}

\section{STRUCTURE AND AMBIDEXTROUS ORGANIZATION}

Research on structural antecedents has focused on creating separate organization units and the use of formal and informal coordinating mechanis ms to stimulate innovation ambidexterity (Duncan, 1976; Christensen 1997; Tushman and O'Reilly, 1996; Jansen, et al., 2006). A mbidexterity can be defined as a firm's ability to operate complex organizational designs that provide for short-term efficiency and long-term innovation (Tushman \& O’Reilly, 1996).

As shown in table 2, Organization theory scholars have long discussed the challenge of using organizational features that make possible both explore as well as exploit (Tushman and O'Reilly 1997, Gibson and Birkinshaw 2004, Siggelkow and Levinthal 2003). Thompson (1967) describes the trade-off between exploitation as efficiency and exploitation as flexibility as a central "paradox of administration" (p. 15).

Scholars first put forward different structural mechanisms to cope with the competing demands facing the organization (Adler, Goldoftas, \& Levine, 1999; McDonough \& Leifer, 1983; Tushman \& O'Reilly, 1996). Conversely, Gibson and Birkinshaw (2004) proposed that ambidexterity arises from a business unit's organizational context.

Table 2: Contradictory Organizational Structure Tensions

\begin{tabular}{|c|c|c|c|}
\hline \multicolumn{2}{|c|}{ SCHOLAR } & \multirow[t]{2}{*}{ EXPLOIT ATION STRUCT URE } & \multirow[t]{2}{*}{ EXPLORATION STRUCT URE } \\
\hline Separate Unit & Single Unit & & \\
\hline $\begin{array}{l}\text { Burns and Stalker } \\
\text { 1961, Duncan 1976, } \\
\text { Ford \& Ford, 1994; } \\
\text { Lawrence \& Lorsch, } \\
\text { 1967; Lewis, } 2000\end{array}$ & $\begin{array}{l}\text { Adler et al., 1999; } \\
\text { Jansen et al., 2005a; } \\
\text { Sheremata, 2000; Gibson } \\
\text { \& Birkinshaw, } 2004\end{array}$ & Mechanistic & Organic \\
\hline
\end{tabular}




\section{CULTURE AND AMBIDEXTROUS ORGANIZATION}

Schein (1985) proposed that culture addresses two fundamental is sues confronting organizations: the need to adapt to external changes, and the need to provide internal integration. Researchers have disagreed about how various types and cultural behaviors affect performance. So me have viewed cultivating a strong culture in which members agree and feel intensity about norms as a potential path to aligning employees with an organization's strategic priorities (Tushman \& O'Reilly, 2002). One the other hand, some have been skeptical of the notion that a strong culture boosts performance, particularly in dynamic environments.

Organizations with a strong culture can induce cognitive and behavioral uniformity among group members (Nemeth \& Staw, 1989; Staw, 2009) create clear and coherent values (Chat man \& Cha, 2002; Saffold, 1988) and expect that members agree with and care intensely about those values (Jackson, 1966; O'Reilly, 1989) because groups tolerate less deviation as cohesion among members intensifies (Kaplan, Brooks, Shesler, King, \& Zaccaro, 2009), even if core values emphasize dissent and creativity (e.g., Flynn \& Chat man, 2001; Sutton \& Hargadon, 1996). Althoght some researchers have questioned how well strong cultures improve bottom-line performance (Saffold, 1988), a growing body of research and a host of salient examples demonstrate how organizations attain strategic advantages through strong cultures (Collins \& Porras, 1994; Gordon \& DiTomaso, 1992; O'Reilly \& Pfeffer, 2000).

Although strong culture organizations and their associated stability generally enjoy better performance than do weaker culture organizations, strong culture organizations are not as adaptive as may be necessary for their long-term survival, because strong cultures are associated with greater adherence to routines and behavioral uniformity. So they are less effective than weaker culture firms in dynamic environments (Boisnier, A., \& Chatman J. A., 2003).

Following table mentions how scholars suggested paradoxical tensions of cultural ambidexterity.

Table 1: Contradictory Organizational Cultural Tensions

\begin{tabular}{|c|c|c|}
\hline SCHOLAR & EXPLOIT ATION CULTURE & EXPLORATION CULTURE \\
\hline $\begin{array}{l}\text { Tushman \& O’Reilly, 1996; T ushman \& Smith, } \\
2002\end{array}$ & Strong & Flexible \\
\hline \multicolumn{3}{|c|}{$\begin{array}{l}\text { Organizations benefit from simultaneously managing strong, stable cult ures while maintaining the flexibility and adaptability } \\
\text { necessary to survive the ebbs and flows of turbulent environments }\end{array}$} \\
\hline $\begin{array}{l}\text { Boisnier, A., \& Chatman J. A., 2002; Schein, } \\
\text { 1988; Ashby’s (1956) }\end{array}$ & Dominant Culture & Subculture \\
\hline \multicolumn{3}{|c|}{$\begin{array}{l}\text { Co-existence of subcultures and a dominant culture when dealing with pivotal and peripheral values. Pivotal values are central to an } \\
\text { organization's functioning, while Peripheral values are desirable but are not believed by members to be essential. Competition } \\
\text { between subcultures enhances the capacity of organizations to adapt to changing conditions. Strong culture firms might become more } \\
\text { agile by allowing subcultures to emerge. Organizations with more variety are better equipped to respond to a complex environment. } \\
\text { Norm variation, generated by subcultures characterized by creativity, can similarly foster innovation and adaptation to dynamic } \\
\text { environments. }\end{array}$} \\
\hline Lewis \& Boyer (2007) & Control & Flexible \\
\hline \multicolumn{3}{|c|}{$\begin{array}{l}\text { Culture of flexibility promoted creativity while control helped with execution and arises from adherence to a norm that promote } \\
\text { adaptability.To promote adaptation, the norms that define an organization's culture need to promote flexibility, risk taking, an } \\
\text { experimentation within the firm. }\end{array}$} \\
\hline L. Wang \& M. Rafiq & Shared Vision & Diversity \\
\hline \multicolumn{3}{|c|}{$\begin{array}{l}\text { Organizational diversity and shared vision are important to achieve either simultaneous or sequential ambidexterity. } \\
\text { Shared vision defined as the organizational values that promote organizational members play an active role in creating their own } \\
\text { organizational cult ure, contrary to the traditional top-down approach (Schein, 1985; Gregory, 1983; Wilkins and Ouchi,1983) or the } \\
\text { strat egic approach to culture, that leaders in an organization create the cult ure (Pettigrew, 1979).However, Diversity is defined as the } \\
\text { extent to which a firm tolerates differences, recognizes, evaluates, and rewards individuals to think originally in a frame-breaking } \\
\text { way, which, in turn, contribute to a rich cognitive pool of ideas, experience, and knowledge (Miller and Friesen, 1983; Popper and } \\
\text { Lipshitz, 1998). }\end{array}$} \\
\hline
\end{tabular}




\section{MANAGEMENT MODEL OF AMBIDEXTROUS ORGANIZATION: HOT CUBE}

Most prior literature has focused on relevance of ambidexterity and organizational performance (Adler, Goldoftas and Levine, 1999; Ahuja and Lampert, 2001; Benner and Tushman, 2002; Gibson and Birkinshaw, 2004; He and Wong, 2004; McDonough and Leifer, 1983). In contrast, far less research has traditionally been devoted to how organizations achieve organizational ambidexterity (Adler et al., 1999; Siggelkow \& Levinthal, 2003). Recently some studies indicate if a firm wants to gain these advantages and want to be ambidextrous; some organizational antecedents should support this strategy. They have started to investigate the antecedents of organizational a mbidexterity and described organizational structures, behavioral contexts, and leadership processes as promoters of ambidexterity (Burgelman's, 1991; Flynn and Chatman 2001).

However a more holistic view is needed to cover previous one-dimensional studies. Our review resulted in the development of a management model that can be applied to describe, analyze, diagnose and promote ambidextrous organizations.

Ambidextrous organizational designs are composed of an interre lated set of organizational factors. None of organizational factors are dependent and all have bilateral relations. According to the principle of strategic fit or alignment, organizational performance is the consequence of fit between two or more factors such as strategy, structure, technology, culture and environment (Burns and Stalker, 1961). Strategic alignment is rooted in contingency theory, which suggests that there is no one best way of organizing (Miller et al., 1984) and must be fitted into its context in order to enhance firm performance (Bergeron et al., 2004). The contingency relationship that has received the most attention has been the one between organizational strategy and organizational structure, starting with Chandler's (1962) thesis that strategy precedes structure, and followed by a large number of studies in large and s mall manufacturing and service firms (Galbraith and Nathanson, 1979; Miller 1987; Freel, 2000). However there are situations where changes in structure lead to changes in strategy, even though strategy has been found to be a more important determinant of structure than structure is of strategy (Amburgey and Dacin, 1994).

An aligned organization will be operating effectively if organization cultures and structures appropriately designed in given strategic situations. It considers the degree of alignment that exists between competitive situations, strategy, culture and structure.

Thus it is expected that ambidextrous management model also be designed according to interaction of critical factors of environment, strategy, culture and structure that are domain of other organizational context. Changing one factor affects, sparks or hampers another's changing.

As ambidexterity seeks the balance of exploitative and explorative activities, it is expected not to be achieved without considering effective interplay of change in these three factors. Moving towards ambidextrous organization requires capable organizations of repeated change management at times of industry transitions (Tushman et al., 1996).

Culture is a socially constructed attribute of organizations which serves as the "social glue" binding organizational elements together (Cameron \& Ettington, 1988; O’Reilly \& Chatman, 1996; Schein, 1996). Changing an institutional culture successfully is difficult and complex, because a deeply imbedded culture tends to evolve only slowly, if at all, and changes to ingrained attitudes and beliefs are often strongly resisted. Research suggests that between $66 \%$ and $75 \%$ of organizational culture change efforts fail. However Organizations tend to develop and value set over time as they adapt and respond to challenges and changes in the environment (Schein, 1996; Sathe, 1985). Thus, complete culture changes should only be undertaken when absolutely essential and must be relevant in the context of improving overall business performance and consistent with strategic imperatives (Hooijberg \& Petrock, 1993; Denison, 1989; Trice \& Beyer, 1993; Cameron \& Quinn, 1999; Kotter, 1995).

Yet organizational cultures do not change simultaneously with strategy changes. In addition strategy has strict relation with culture. Even strategy changes structure it can be hampered by culture and not implemented correctly. 
To be ambidextrous, organizations have to reconcile internal tensions and conflicting demands in their task environments (Figure 2). Some academics identified the roles of organizational structures, cultures, and routines to manage contradictions. According to the literature several authors outline the various organizational antecedents and their paradoxical faces that can be instrumental in finding a balance between the two types of explo ratory and exploitatively activities and thus our model considered following paradoxes with their strict interrelation.

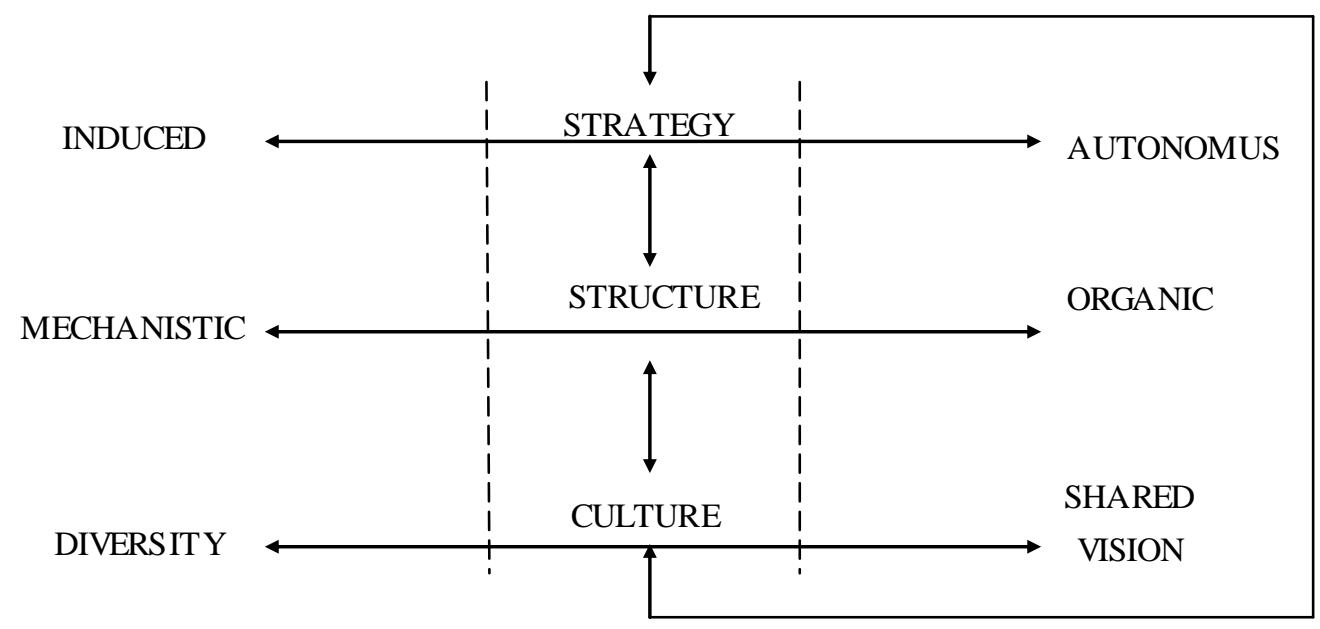

BALANCED

Fig 2. Interrelation of Paradoxical Features of Ambidexterity Antecedents

Composition of paradoxical types of strategy, structure and culture can produce various sorts of organizational with more or less efficiency or flexibility. According to figure 3, each factor assumes as an axes of $\mathrm{X}, \mathrm{Y}$ and $\mathrm{Z}$. The large cube is fitted these axes which each edge is divided into 3 parts: explorative, exploitative and balanced features. This forms 27 small cubes with a specific characteristic caused from structural, strategic and cultural behaviors. Each organization according to its past, present and future orientations can be more fitted to one of these 27 cubes.

Achieving balanced condition may occur in only one or two factors, yet to be an ambidextrous organization and guarantee business continuity, this model presents the inside cube, showed in red, as the "Hot Cube", which completely has a balanced behavior as it's strategy, structure, and culture is ambidextrous.

The whole cubes are performing in a dynamic environment that changes can shift the organization from one cube to another. However sustainable success can be achieved only if the organization enhances their capabilities to reaches the "HOT CUBE".

Fig 3. Management Model of Hot Cube

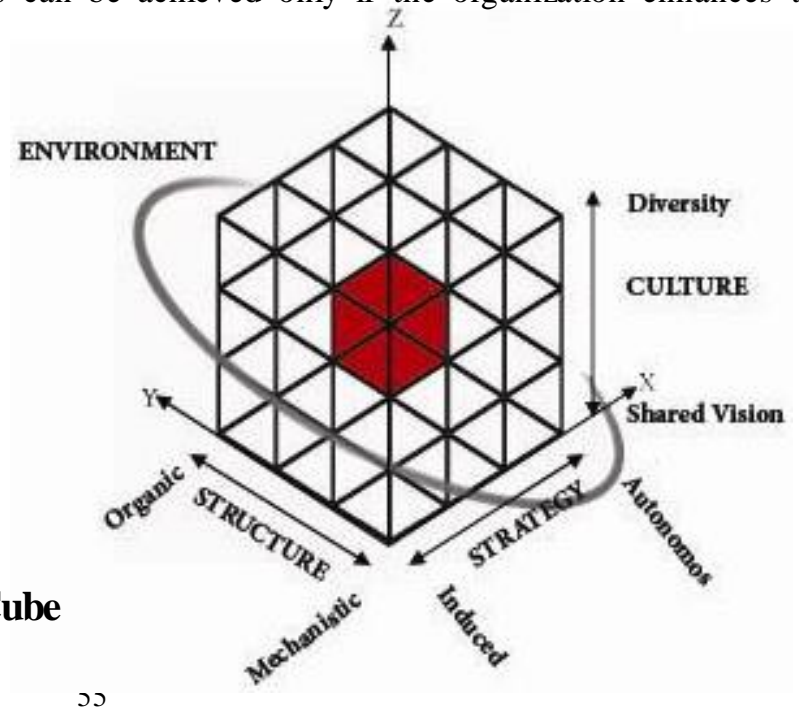




\section{CONCLUSION}

According to the principle of strategic alignment, organizational performance is the consequence of fit between two or more factors such as strategy, structure, culture and environment (Burns and Stalker, 1961). Strategic alignment is rooted in contingency theory, which suggests that there is no one best way of organizing (Miller et al., 1984) and must be fitted into its context in order to enhance firm performance.

These three basic organizational factors; strategy, structure and culture, have strong interrelationships. An aligned organization will be operating effectively if organization cultures and structures appropriately designed in given strategic situations. The contingency relationship that has received the most attention suggests strategy precedes structure. On the other hand, Strategy has strict relation with culture, while organizational culture does not change simultaneously with strategy changes. Even strategy changes structure it can be hampered by culture and not implemented correctly.

As ambidexterity seeks the balance of exp loitative and explorative activities, it is expected not to be achieved without considering effective alignment of factors such as strategy, structure and culture which is environment. Some academics identified the roles of organizational structures, cultures, and strategy to manage contradictions.

Composition of parado xical types of strategy, structure and culture can produce various sorts of organizations with more or less efficiency or flexibility. This research proposed a management model to describe, analy ze, diagnose and promote organizations toward ambidexterity and suggests that sustainable success can be achieved only if the organizations continuously balance paradoxical tensions of strategy, structure and culture concurrently. 


\section{REFERENCES}

Adler, P., Goldoftas, B., \& Levine, D. (1999). Flexibility versus efficiency? A case study of model changeovers in the Toyota production system. Organization Science, 10: 43-68.

Ahuja, G., \& Lampert, C. (2001). Entrepreneurship in the large corporation: A longitudinal study of how established firms create breakthrough inventions. Strategic Management Journal, 22: 521-543.

Alvesson, M. (2002). Understanding Organizational Culture. London: Sage.

Amburgey TL, Dacin T. (1994). As the left foot follows the right? The dynamics of strategic and structural change. Acad Manage J;37(6):1427 - 52.

Ancona, D. G., Goodman, P. S., Lawrence, B. S., \& Tushman, M. L. (2001). Time: A new research lens. Academy of Management Review, 26: 645-663.

Ashby, W.R. (1956). An introduction to cybernetics. London: Chapman \& Hall Ltd.

Auh, S., \& Menguc, B. (2005). Balancing exploration and exploitation: The moderating role of competitive intensity. Journal of Business Research, 58: 1652-1661.

Beigy MH.(2010). MA Thesis (Presenting the model of key success factors to increase organizational creativity and learning in Iran airports).

Benner, M. J., \& Tushman, M. L. (2003). Exploitation, exploration, and process management: The productivity dilemma revisited. Academy of Management Review, 28: 238-256.

Bennet R, Gabiel H.1999. organizational factors and knowledge management with large marketing department: an empirical study. J knowledge management 1999; 3(3) 2-2-25.

Bettenhausen, K., \& Murninghan, J. K. (1991). The development and stability of norms in groups facing structural change. Administrative Science Quarterly, 36: 20-35.

Blau, P.M. (1970). Decentralization in bureaucracies. In M. N. Zald (Ed.), Power in organizations. Nashville, TN: Vanderbuilt University Press.

Boisnier, A., \& Chatman,J. (2002). The Role of Subcultures in Agile Organizations, Harvard Business School, 2-091.

Boisnier, A., \& Chatman, J. (2003). Cultures and subcultures in dynamic organizations. In Mannix, E., and Petersen, R. (Eds.), The dynamic organization: 87-114. Mahwah, NJ: Lawrence Erlbaum Associates.

Brown, J. S., \& Duguid, P. (2001). Knowledge and organization: A social-practice perspective. Organization Science, 12: 198-213.

Burgelman, R. A. (1991). Intraorganizational ecology of strategy making and organizational adaptation: Theory and field research. Organization Science, 2: 239-262.

Burgelman, R. A. (2002). Strategy as vector and the inertia of coevolutionary lock-in. Administrative Science Quarterly, 47: 325-357.

Burns, T., \& Stalker, G. M. (1961). The management of innovation. London: Tavistock.

Cameron, K.S. and Ettington, D.R. (1988). The conceptual foundations of organizational culture. Higher Education: Handbook of Theory and Research, New York: Agathon, 356-396.

Cameron, K.S. and Quinn, R.,E. (1999). Diagnosing and Changing Organizational Culture. Reading, MA: Addison Wesley.

Certo, S.C. \& Peter, J.P. 1991. Strategic Management: concepts and application. New York: McGraw-Hill.

Chandler, Alfred D., Jr. (1962), Strategy and Structure - Chapters in the History of the American Industrial Enterprise. 
Chat man, J. A. \& Cha, S.A. (2002).In press. Leading through organizational culture. In, S. Chowdhury (Ed.), Next generation business series:Leadership: Financial Times-Prentice Hall Publishers.

Christensen, CM. (1997). The Innovator's Dilemma. Boston: Harvard Business School Press.

Collins, J.C. \& Porras, J.I. (1994). Built to last : Successful habits of visionary companies. New York: Harper Business.

Daulatram B. Lund. (2003). Organizational culture and job satisfaction, Journal of Business \& Industrial Marketing, 18(3): 219 - 236.

Davenport T, prusak L. (1998).Working knowledge; how organizational manage what they know. Boston: Harvard Business schoolpress.

Denison, D. (1989). Corporate Culture and Organizational Effectiveness. New York: Wiley.

Dewar, R., \& Werbel, J. (1979). Universalistic and contingency predictions of employee satisfaction and conflict. Administrative Science Quarterly, 24, 426-448.

Duncan, R. (1976). The ambidextrous organization: Designing dual structures for innovation. In R. H. Killman, L. R. Pondy, \& D. Sleven (Eds.), The management of organization, New York: North Holland,1: 167-188.

Eisenhardt, K. M. (2000). Paradox, spirals, ambivalence: The new language of change and pluralis m. Academy of Management Review, 25: 703-705.

Fiol, C. 1991. Managing culture as a competitive resource: An identity-based view of sustainable competitive advantage. Journal of Management, 17(1): 191-211.

Floyd, S., \& Lane, P. (2000). Strategizing throughout the organization: Managing role conflict in strategic renewal. Academy of Management Review, 25: 154-177.

Flynn, F., \& Chatman, J. A. (2001). Strong cultures and innovation: Oxymoron or opportunity? In Cart wright, S., Cooper, C., Earley, C., Chatman, J., Cummings, T., Holden, N., Sparrow, P. \& Starbuck, W. et al., (Eds.), International handbook of organizational culture and climate: $263-287$. Sussex: John Wiley \& Sons.

Ford, J. D., \& Ford, L. W. (1994). Logics of identity, contradiction, and attraction in change. Academy of Management Review, 19: 756-795.

Freel, M.S. (2000). Strategy and Structure in Innovative Manufacturing SMEs : The Case of an English Region, Small Business Economics, 15, 27-45.

Galbraith, J.R. and Nathanson, D. (1979). The Role of Organizational Structure and Process in Strategy Implementation. In Strategic Management : A New View of Business Policy and Planning, Schendel, D. and Hofer, C.W. (Eds.), Boston : Little, Brown, 249-283.

Gavetti, G., \& Levinthal, D. (2000). Looking forward and looking backward: Cognitive and experiential search Administrative Science Quarterly, 45: 113-137.

Gerwin, D., \& Kolodny, H. (1992). Management of advanced manufacturing technology: Strategy, organization, and innovation. New York: Wiley-Interscience.

Germain, R. (1996). The role of context and structure in radical and incremental logistics innovation adoption. Journal of Business Research, 35:117-127.

Ghemawat, P., \& Ricart i Costa, J. 1993. The organizational tension between static and dynamic efficiency. Strategic Management Journal, 14: 59-73.

Ghoshal, S., \& Bartlett, C. (1994). Linking organizational context and managerial action: The dimensions of quality in management. Strategic Management Journal, 15: 91-112.

Gibson, C. B., \& Birkinshaw, J. (2004). The antecedents, consequences and mediating role of organizational ambidexterity. Academy of Management Journal, 47: 209-226. 
Gordon, G. G. \& DiTomaso, N. (1992). Predicting corporate performance from organizational culture. Journal of Management Studies, 29: 783-798.

Gregory, K.L. (1983). Native-view paradig ms: Multiple cultures and culture conflicts in organizations. Administrative Science Quarterly, 28, 359-376.

Gupta, A. K., Smith, K. G., \& Shalley, C. E. (2006). The interplay between exploration and exploitation. Academy of Management Journal, 4: 693-706.

Habib, Mohammed/Victor, Bart (1991), Strategy, Structure, and Performance of U.S. Manufacturing and Service MNCs, in: Strategic Management Journal,12: 589 - 606.

Hamel, G., \& Prahalad, C. K. (1993). Strategy as stretch and leverage. Harvard Business Review, 71: 75-84.

Hannan, M. T., \& Freeman, J. (1977). The population ecology of organizations. A merican Journal of Sociology, 82:929-964.

He, Z. L., \& Wong, P. K. (2004). Exploration vs. exploitation: An empirical test of the ambidexterity hypothesis. Organization Science, 15: 481-494.

Hooijberg, R.and Petrock, F.(1993). On cultural change: Using the competing values framework to help leaders to a transformational strategy. Human Resource Management, 32: 29-51.

Hunger, J.D., and Wheelen, T.L. (2007) Essentials of Strategic Management. New Jersey: Pearson.

Jackson, J. (1966). A conceptual and measurement model for norms and roles. Pacific Sociological Review, 9: $35-47$.

James, L., James L. \& Ashe D. (1990). The Meaning of organizations: the role of cognition and values. In P. Schneider (ed.), Organizational Climate and Culture, San Francisco, CA: Jossey-Bass, 32 - 54.

Janićijević,N., (2013). The Mutual Impact of Organizational Culture and Structure. Economic Annals, $8(198)$.

Jansen, J. J. P., van den Bosch, F. A. J., \& Volberda, H. W. (2006). Exploratory innovation, exploitative innovation, and performance: Effects of organizational antecedents and environmental moderators. Management Science, 52(11): 1661-1674.

Johnson, G., Scholes, K, \& Whittington, R., (2008), Exploring Corporate Strategy: Te xts and Cases,8th Edition .Prentice Hall International, United Kingdom.

Kaplan, S., Brooks-Shesler, L., King, E. B., \& Zaccaro, S. (2009). Thinking inside the bo x: How conformity promotes creativity and innovation. In E.A. Mannix, M.A. Neale \& J.A. Goncalo (Eds.), Research on managing groups and teams: Creativity in groups, vol. 12: 229-265, Emerald Group Publishing Limited

Kotter, J. P. (1995). Leading change: Why transformation efforts fail. Harvard Business Review, MarchApril: 59-67.

Lawrence, P., \& Lorsch, J. (1967). Organization and environment: Managing differentiation and integration. Boston: Harvard University.

Levinthal, D., \& March, J. (1993). Myopia of learning. Strategic Management Journal, 14: 95-112.

Lewis, M. W. (2000). Exploring paradox: Toward a more comprehensive guide. Academy of Management Review, 25: 760-777.

Lewis, M. W., Boyer, K. K. (2007), “Innovation-supportive Culture: The Impact of Organizational Values on Process Innovation", Journal of

Operations Management, 25: 871-884

Lubatkin, M. H., Simsek, Z., Ling, Y., \& Veiga, J. F. (2006). A mbidexterity and performance in small- to medium sized firms: The pivotal role of top management team behavioral integration. Journal of Management, 32(5):646-672. 
Ly les, M., and Schwenk, C. (1992) Top management, strategy and organizational knowledge structures. In: Journal of Management Studies, 29(2): 155-174.

Martin, J. (2002). Organizational Culture: Mapping the Terrain. London: Sage.

McDonough, E. F., \& Leifer, R. (1983). Using simultaneous structures to cope with uncertainty. Academy of Management Journal, 26: 727-735.

McGill, M. E., Slocum, J. W., \& Lei, D. (1992). Management practices in learning organizations. Organization Dynamics, 21(1): 5-17.

Mehta, S. and Krishnan V.R. (2004), "Impact of Organizational Culture and Influence Tactics on Transformational Leadership", Journal of Management and Labor Studies, 29(4):281-290.

Miller, D. (1987). Strategy Making and Structure : Analysis and Implications for Performance. Academy of Management Journal, 30 (1) 7-32.

Miller, D. and Friesen, P. H. (1983). Strategy-making and environment: The third link. Strategic Management Journal, 4, 221-235.

Miller, D., \& Friesen, P. H. (1984). Organizations: A quantum view. Englewood Cliffs, NJ: Prentice Hall.

Miller, D., \& Friesen, P. H. (1986). Generic strategies and performance: An empirical examination with American data Part I: Testing Porter. Organization Studies, 7(1): 37-55.

Naranjo-Valencia, J.C., Jimenez-Jimenez, D., and Sanz-Valle, R., (2011). "Innovation or imitation?The role of organizational". Management Decision 49 (1): 55-72.

Nemeth, C., \& Staw, B. M. (1989). The tradeoff of social control and innovation in groups and organizations. Advances in Experimental Social Psychology,22: 175-210.

O’Reilly, C. A. \& Pfeffer, J. (2000). Hidden value: how great companies achieve extraordinary results with ordinary people. Boston: Harvard Business School Press. Pottruck, D. S., \& Pearce, T. 2001. Clicks and mortar: passion-driven growth

O'Reilly, C.A. and Chatman, J.A. (1996). Culture as social control: Corporations, cults, and commitment. In Staw, B.M. and Cummings, L.L. (Eds.) Research in Organizational Behavior,. Greenwich, CT: JAI Press, 18: $157-200$

O'Reilly, Charles A. and Tushman, Michael L. (2008). A mbidexterity as a dynamic capability: Resolving the innovator's dilemma. Research in Organizational Behavior, 28: 185-206.

O'Reilly, Charles A. and Tushman, Michael L. (2011). Organizational ambidexterity in action: How managers explore and exploit. California Management Review, 53: 1-18.

O'Reilly, C. (1989). Corporations, culture, and commitment: Motivation and social control in organizations. California Management Review, 314: 9-25.

Popper, M. and Lipshitz, R. (1998). Organizational learning mechanis ms: A structural and cultural approach to organizational learning. Journal of Applied Behavioral Science, 34:161-179.

Saffold, G. S. (1988). Culture traits, strength, and organizational performance: Moving beyond "strong" culture. Academy of Management Review, 13: 546-558.

Sanchez, R., Heene, A., \& Thomas, H. (1996). Dynamics of competence-based competition. New York:Wiley \& Sons.

Sathe, V. (1985). Culture and Related Corporate Realities. Homewood, IL: Irwin.

Schein, E. (1985). Organizational culture and leadership. Jossey-Bass, San Francisco, CA.

Schein, E. 1988. Organizational socialization and the profession of management. Sloan Management Review, 30: 53-65. 
Schein, E. (1996). Culture: The missing concept in organizational studies. Administrative Science Quarterly, 41: 229-240.

Schein E. (2004). Organizational culture and leadership. Thousand Oaks: Sage.

Sheremata, W. (2000). Centrifugal and centripetal forces in radical new product development under time pressure. Academy of Management Review, 25: 389-408.

Siggelkow, N., \& Levinthal, D. A. (2003). Temporarily divide to conquer: Centralized, decentralized, and reintegrated organizational approaches to exploration and adaptation. Organization Science, 14: 650-669.

Simsek, Z. (2009). Organizational Ambidexterity: Towards a Multilevel Understanding. Journal of Management Studies, 46(4): 597-624.

Simsek, Z., Heavey, C., Veiga, J. F., \& Souder, D. (2009). A Typology for Aligning Organizational Ambidexterity's Conceptualizations, Antecedents, and Outcomes. Journal of Management Studies, 46(5): 864-894.

Singh, S.K. (2011). Organizational Innovation as Competitive Advantage During Global Recession. The Indian Journal of Industrial Relations, 46(4):165-185.

Smith,W. K., \& Tushman, M. L. (2005). Managing strategic contradictions: A top management model for managing innovation streams. Organization Science, 16: 522-536.

Sutton, R. I. \& Hargadon, A. (1996). Brainstorming groups in context: Effectiveness in a product design firm. Administrative Science Quarterly, 41: 685-718.

Thompson, J. D. (1967). Organizations in action. New York: McGraw Hill.

Trice, H. and Beyer, J.(1993). The Cultures of Work Organizations. Englewood Cliffs, NJ: Prentice Hall.

Tushman, M. L., \& O'Reilly, C. A. (1996). A mbidextrous organizations: Managing evolutionary and revolutionary change. California Management Review, 38: 8-30.

Tushman, M. L., \& O'Reilly, C. A. (1997). Winning through innovation: A practical guide to managing organizational change and renewal. Cambridge, MA: Harvard Business School Press.

Tushman, Michael L. and O'Reilly, Charles A. (2002). Winning through innovation: A practical guide to leading organizational change and renewal. Boston, MA: Harvard University Press.

Volberda, H., Baden-Fuller, C., \& van den Bosch, F. A. J. (2001). Mastering strategic renewal: Mobilizing renewal journeys in multi-unit firms. Long Range Planning, 34: 159-178.

Wang, C. L. and Rafiq, M. (2009). Organizational diversity and shared vision: resolving the paradox of exploratory and exploitative learning. European Journal of Innovation Management, 12(1): 86-101.

Wei L., Liu J. and Herndon N.C. (2011). SHRM and Product Innovation: Testing The Moderating Effects of Organizational Culture and Structure in Chinese Firms. The International Journal of Human Resource Management, 22 (1):19-33.

Wiklund, J. (1999). The sustainability of the entrepreneurial orientation-performance relationship. Entrepreneurship Theory and Practice, 24, 37-48.

Wilderom CPM, Glunk U, Maslowski R. (2000). Organizational culture as a predictor of organizational performance. In handbook of Organizational culture and climate: NM Ashkanasy, CPM. Wilderom, MF Peterson(eds). Sage publication,Inc.,Thousand Oaks, CAL,193-210.

Zheng W., Yang B. \& McLean G.N. (2010). Linking Organizational Culture, Structure, Strategy, and Organizational Effectiveness: Mediating Role of Knowledge Management. Journal of Business Research, 63: 763-771. 